\title{
健診における乳腺・甲状腺超音波検査の検討
}

\author{
高柳 紀子1) 南里 和秀 浪川かおる 高橋 明子 \\ 池田 紀之 久保田光博 ${ }^{2}$ 安藤 泰彦 ${ }^{3)}$ 日野原茂雄 ${ }^{4)}$
}

〈目的〉乳癌, 甲状腺癌の早期発見は, 自己健診 あるいは, 集団健診による腫瘤の発見である。しかし， 集団健診にて乳房, 甲状腺の超音波検查(以下 US と略 す)を施行している施設はあまりみられない。今回我々 は，集団健診での乳房及び甲状腺超音波検査と視触診 （以下 PEと略す）の比較検討を行った。

〈対象及び方法〉検查対象者を I 群とII群に分け比 較検討を行った。I 群は, 1988 年 8 月の 1 力月間に当 院健診センターを受診した女性 385 名であり, II群は 1987 年 9 月から 1989 年 9 月に検查を行った受診者 421 名 (ただし甲状腺は 48 名)である。I 群は, 乳房, 甲状腺ともに受診者全員にUSと PEを施行した群で あり PEの結果はUSの検者にはわからないようにし 先入観を排除した。II群は, PEの異常者のみ US を施 行した群である。なお, 今回の検討では腫瘤性病変を 対象とした乳腺症は除外した。装置は, 横河 RT2600, 3000 (リニア型), アロカSSD630 (リニア, メカニカ ルセクタ型), 日立 EUB450 (リニア型), 東芝 SAL30A (リニア型) の 6 台を適宜使用した。

探触子の周波数は，東芝が $5 \mathrm{MHz}$ で，それ以外は， $7.5 \mathrm{MHz}$ を使用した。

〈結 果〉乳房について, US 上腫瘤性病変の検出 率は I 群で 51 例 $(13.2 \%)$ ，II群では 87 例 (20.7\%) であった。また, 甲状腺については, 腫瘤性病変の検 出率は, I 群で 90 例 $(23.4 \%)$, II 群では, 43 例 (90.0\%) であった。I群において, US で所見を認め たが, PEで異常を認めなかったものが, 乳房で 46 例 $(12.6 \%)$ ，甲状腺で 86 例 $(22.6 \%)$ 存在した。

〈考 察〉乳癌は相対的にみて, 西欧諸国に高率に 発生しているが, 近年わが国での罹患率は著しく増加 している。一方, 甲状腺癌は他の癌と比べて予後は比
較的良好であるが, 乳癌同様, 甲状腺癌の死亡率も増 加傾向にある。これら乳癌, 甲状腺癌の治癒率を向上 させ，かつ死亡率を低下させるためには，集団健診や 自己健診で腫瘤を早期に発見し適切な治療を施すこと が大切と思われる。乳癌の基本的な検査方法である $\mathrm{PE}$ は, 乳房の形態的構造, 腫瘤の性状, 医師の熟練度 の差，性周期などにより大きく影響を受けている。今 回の検討において, PEで異常を認め, かつUSでも何 等かの所見を認めるもの（II群）が, 乳房で 87 例 (20.7\%) 甲状腺で，43 例 $(90.0 \%)$ で存在した。しか し, PEで異常を認めずUSで所見を認めたもの（I 群)が, 乳房で 46 例(12.6\%), 甲状腺で 86 例 (22.6\%) と PEでは, 判定のできないものが少なからず存在し た。以上より, PEで触知不能な腫瘤性病変をUS では 容易にかつ非浸襲的に発見することができる。今回の 検討の結果, 第 1 次健診で US を施行することは, PE で触れる限界以上の微少癌を容易に発見することがで き,さらに, 将来的には覀性を疑う腫瘤を直ちにその 場において超音波ガイド下の穿刺吸引することも可能 であると思われる。US は手軽な検査法ではあるが, 反 面機種による画像の違い, 皮膚と探触子の介在物質, 検者の教育など検討すべき問題点は残されている。し かし, 今後第 1 次健診の段階で US を施行することは 必要不可欠であると思われる。

〈まとめ〉1. 視触診で触知不能な腫瘤性病変を超 音波では容易に発見できる。

2. 将来的には,第一次健診で超音波を使用すること によりその場で穿刺吸引ができ質の高いスクリーニン グも期待できる。

3. 問題点として機種による画像の違い, 皮膚と探触 子の介在物質, 検者の教育などがあげられる。

\section{Ultrasonic Survey of Breast and Thyroid in AMHTS}

\footnotetext{
1) 東海大学病院中央臨床検査センター

2) 同 第二外科学教室

3) 同 臨床病理学教室

4) 同 健診センター
} 